\section{July-3 August 2001}

13th International Conference on Crystal Growth, in conjunction with the 11th International Conference on Vapor Growth and Epitaxy. Kyoto, Japan. [Contact: E-mail: info@iccg.doshisha.ac.jp].

\section{July-4 August 2001}

12th International Clay Conference. Bahía Blanca, Argentina. Held at the Universidad Nacional del Sur. [Contact: Dr. Fernanda Cravero, Departamento de Geologia, Universidad Nacional del Sur, San Juan 670, 8000 Bahía Blanca, Argentina. Fax: 54 (291) 459 5148; E-mail: 12icc@criba.edu.ar; Info: http://www.12icc.criba.edu.ar].

\section{July-3 August 2001}

Denver X-ray Conference. Denver, Colorado, USA. [Contact: Ms. Denise Flaherty, International Centre for Diffraction Data, 12 Campus Boulevard, Newtown Square, PA 19073-3273, USA. Tel: 1 (610) 325 9814; Fax: 1 (610) 325 9823; E-mail: dxc@icdd.com; Info: http:// www.dxcicdd.com/01].

\section{5-31 August 2001}

20th European Crystallographic Meeting. Kraków, Poland. [Contact: Prof. Stanislaw Hodorowicz, Jagiellonian University, Faculty of Chemistry, ul. R. Ingardena 3, 30-060 Kraków, Poland. Tel: 48 (12) 336377 x267; Fax: 48 (12) 34 05 15; E-mail: ecm2001@trurl.uj.edu.pl; Info: http:// www.ch.uj.edu.pl/ecm2001.htm].

\section{9-13 September 2001}

ICNS 2000 International Conference on Neutron Scattering. München, Germany. At Technische Universität München. [Contact: ICNS 2000 Conference Office, Technische Universität München, Physik Department E13, D-85747 Garching, Germany. Tel: 49 (89) 2891 2452; Fax: 49 (89) 2891 2473; E-mail: info@icns2001.de; Info: http:// www.icns2001.de].

\section{5-12 October 2001}

28th Annual Conference of Federation of Analytical Chemistry and Spectroscopy Societies. Detroit, Michigan, USA. [Contact: Cindi Lilly, FACSS, 1201 Don Diego Avenue, Santa Fe, NM 87505, USA. Tel: 1 (505) 820 1648; Fax: 1 (505) 989 1073; E-mail: jsjoberg@trail.com; Info: http://facss.org/info.htm].

\section{6-30 November 2001}

Fall Meeting of the Materials Research Society. Boston, Massachusetts, USA. [Contact: Materials Research Society, 506 Keystone Drive, Warrendale, PA 15086-7573, USA. Tel: 1 (724) 779 3003; Fax: 1 (724) 779 8313; E-mail: info@mrs.org; Info: http://www.mrs.org].

\section{6-30 May 2002}

ACA'02 American Crystallographic Association Annual Meeting. San Antonio, Texas, USA. [Contact: Raymond E. Davis, Department of Chemistry and Biochemistry, University of Texas at Austin, Austin, TX 78712-1167, USA. Tel: 1 (512) 471 4440; Fax: 1 (512) 471 8696; E-mail: redavis@mail.utexas.edu; Info: http://hwi.buffalo.edu/aca].

\section{July -2 August 2002}

Denver X-ray Conference. Denver, Colorado, USA. [Contact: Ms. Denise Flaherty, International Centre for Diffraction Data, 12 Campus Boulevard, Newtown Square, PA 19073-3273, USA. Tel: 1 (610) 325 9814; Fax: 1 (610) 325 9823; E-mail: dxc@icdd.com; Info: http:// www.dxcicdd.com/02].

\section{6-15 August 2002}

19th IUCr General Assembly and International Congress of Crystallography. Jerusalem, Israel. [Contact: Secretariat XIX IUCr, Post Office Box 50006, Tel Aviv 61500, Israel. Tel: 972 (3) 515 0009; Fax: 972 (3) 5175674 or 972 (3) 514 0077; E-mail: iucr@kenes.com; Info: http://www.kenes.com/ iucr].

\title{
Short Courses and Workshops
}

\section{3-5 April 2000}

Quantitative Analyse in der Zement-, Kalk-, und Gipsindustrie. Halle, Germany. Includes: Quantitative Rietveld analysis-a breakthrough; Combined XRF and XRD analytics; and new automated solutions in quantitative analysis. Sponsored by Institut für Geologische Wissenschaften der Martin-Luther Universität Halle, in conjunction with Bruker AXS GmbH. Limited to about 50 participants. [Contact: Prof. Dr. H. Pöllmann, Institut für Geologische Wissenschaften, Martin-Luther Universität Halle, Domstrasse 5, D-06108 Halle (Saale), Germany].

\section{1-2 May 2000}

Visualizing Data: Building Statistical Models for Data. Alexandria, Virginia, USA. Sponsored by the American Statis- tical Association. Presented by William, S., Cleveland; held at the George Washington University Graduate Center. The course will present visualization tools that provide deep insight into the structure of data. The course is intended for anyone who has data to analyze. [Contact: E-mail: patricia@amstat.org; Info: http://www.amstat.org/education].

\section{1-5 May 2000}

ICDD Clinic on X-ray Fluorescence Spectrometry. Session I: Fundamentals. Newtown Square, Pennsylvania, USA. Covering basics of X-ray spectra, instrumentation design, methods of qualitative and quantitative analysis, specimen preparation, and applications of both wavelength and energy-dispersive spectrometry. Cost of session is $\$ 1,250$, which includes textbook, lecture notes, use of computers 
(where applicable), and lunch. [Contact: Education Coordinator, International Centre for Diffraction Data, 12 Campus Boulevard, Newtown Square, PA 19073-3273, USA. Tel: 1 (610) 325 9814; Fax: 1 (610) 325 9823; E-mail: clinics@icdd.com; Info: http://icdd.com/education/ clinics.htm].

\section{2-5 May 2000}

School on Structure Determination and Refinement using Powder Diffraction Data. Mérida, Venezuela. [Contact: Prof. Miguel Delgado, Universidad de Los Andes, Departamento de Química, Laboratorio de Cristalografia, Apartado 40, Mérida 5101, Venezuela. Tel: 58 (74) 401 372; Fax: 58 (74) 401 286; E-mail: migueld@ ciens.ula.ve; Info: http:// www.ciens.ula.ve/ $\sim \operatorname{lndrx}]$.

\section{8-10 May 2000}

Rietveld Method Short Course. Atlanta, Georgia, USA. This three-day short course will deal with the principles and techniques of Rietveld analysis. In addition to the provision of a solid theoretical underpinning, the student will obtain hands-on experience with data analysis along with expert guidance on problem solving. Students are encouraged to bring their own data sets. Instructors are R. A. Young, Robert Von Dreele, and Angus P. Wilkinson. Cost \$995. [Contact: Prof. R. A. Young, School of Physics, Georgia Institute of Technology, Atlanta, GA 30332-0430, USA or Georgia Tech Continuing Education, Post Office Box 93686, Atlanta, GA 30377-0686, USA. Tel: 1 (404) 385 3501; Fax: 1 (404) 894 8925; Info: http://www.conted.gatech.edu/register].

\section{8-12 May 2000}

ICDD Clinic on X-ray Fluorescence Spectrometry. Session II: Advanced Methods. Newtown Square, Pennsylvania, USA. Emphasizing quantitative methods, use of automated X-ray spectrometers, review of mathematical matrix correction procedures, and new developments. Cost of session is $\$ 1,250$, which includes textbook, lecture notes, use of computers (where applicable), and lunch. [Contact: Education Coordinator, International Centre for Diffraction Data, 12 Campus Boulevard, Newtown Square, PA 19073-3273, USA. Tel: 1 (610) 325 9814; Fax: 1 (610) 325 9823; E-mail: clinics@icdd.com; Info: http://icdd.com/education/ clinics.htm].

\section{7-20 May 2000}

EMAS2000 4th Regional Workshop on Electron Probe Microanalysis Today-Practical Aspects. Trest, Czech Republic. Organized by the European Microbeam Analysis Society. Including, among other topics, analytical electron microscopy, electron spectroscopies, X-ray spectrometry. Consisting of invited lectures, poster sessions, and panel discussions. The working language is English. [Contact: Dr. Karel Masek, Faculty of Mathematics and Physics, Charles University, V. Holesovickach 2, CZ-18000 Prague 8, Czech Republic. Tel: 420 (2) 2191 2753; Fax: 420 (2) 688 5095; E-mail: emas2000@mbox.troja.mff.cuni.cz; Info: http:// www.mff.cuni.cz/eng/news/emas2000.htm].
20 May 2000

ICDD X-ray Powder Diffraction Workshop. Barcelona, Spain. Held as part of EPDIC-7. [Contact: Mrs. Gloria Casanova, Ultramar Express, S. A., c/Diputació, 238-244, 3er, E-08007 Barcelona, Spain. Tel: 34 (93) 482 7140; Fax: 34 (93) 482 7158; E-mail: gcasanova@uex.es or epdic7@icmab.es; Info: http://icmuix.icmab.es/epdic7].

\section{5-9 June 2000}

ICDD Clinic on X-ray Powder Diffraction. Session I: Fundamentals. Newtown Square, Pennsylvania, USA. Covering instrumentation, specimen preparation, data acquisition, and qualitative phase analysis. Cost of session is $\$ 1,250$, which includes textbook, lecture notes, use of computers (where applicable), and lunch. [Contact: Education Coordinator, International Centre for Diffraction Data, 12 Campus Boulevard, Newtown Square, PA 19073-3273, USA. Tel: 1 (610) 325 9814; Fax: 1 (610) 325 9823; E-mail: clinicx@icdd.com; Info: http://icdd.com/education/ clinics.htm].

\section{2-16 June 2000}

ICDD Clinic on X-ray Powder Diffraction. Session II: Advanced Methods. Newtown Square, Pennsylvania, USA. Emphasizing computer-based methods of data collection and interpretation, for both qualitative and quantitative phase analysis. Cost of session is $\$ 1,250$, which includes textbook, lecture notes, use of computers (where applicable), and lunch. [Contact: Education Coordinator, International Centre for Diffraction Data, 12 Campus Boulevard, Newtown Square, PA 19073-3273, USA. Tel: 1 (610) 325 9814; Fax: 1 (610) 325 9823; E-mail: clinics@icdd.com; Info: http:// icdd.com/education/clinics.htm].

\section{5-17 June 2000}

Second International Workshop on Small-angle X-ray Scattering with NanoSTAR. Leoben, Austria. [Contact: Dr. Kurt Erlacher, Material Center Leoben, Erich Schmid Institute for Materials Science, Jahnstrasse 12, A-8700 Leoben, Austria. Tel: 43 (3842) 455 1131; Fax: 43 (3842) 455 126; E-mail: kurt.erlacher@uni-leoben.ac.at; Info: http:// www.oeaw.ac.at/esi/english/events/workshop-2000.html].

\section{8-21 September 2000}

DGK-AK4 Arbeitstagung: Strukturbildungen in Nichtkristallinen Materialien-Phasen- und Glasübergänge, Keimbildung und Kristallisation. Wolfersdorf, Germany. [Contact: Dr. rer. nat. Bernd Müller, Institut für Physicalische Chemie, Friedrich-Schiller-Universität Jena, Lessingstrasse 10, 07743 Jena, Germany. Tel: 49 (3641) 948 317; Fax: 49 (3641) 948 302; E-mail: bernd.mueller@unijena. de; Info: http://www.uni-jena.de/chemie/dgk-ak4/ neu_ank.html].

\section{4-29 September 2000}

First International Workshop on Physical Characterization of Pharmaceutical Solids. Lancaster, Pennsylvania, USA. The main themes are solid state characterization, polymorphism, non-ambient XRD, thermal analysis, structure determination, morphology, processing effects, patent and regulatory issues. [Contact: Angeline Zakrzewski, ASSC, 
Inc., 520 Anthony's Drive, Exton, PA 19341, USA. Tel: 1 (610) 594 2081; Fax: 1 (610) 594 2082; E-mail: angeline@assci.com; Info: http://www.assci.com/ $\sim$ marekz/iwpcps-1.htm].

\section{4-8 October 2000}

Workshop on Structure Determination and Refinement from Powder Diffraction Data. Bayreuth, Germany. Organized by the Powder Diffraction Group of the DGK. The language of the workshop is English. [Contact: Robert E. Dinnebier, Laboratory of Crystallography, University of Bayreuth, D-95440 Bayreuth, Germany. Tel: 49 (921) 553 880; Fax: 49 (921) 553 770; E-mail: robert.dinnebier@unibayreuth.de; Info: http://www.uni-bayreuth.de/departments/ crystal/workshop 2000$]$.

\section{7-19 September 2001}

Workshop on Sources of Measurement Error in Electron Beam X-ray Microanalysis. Gaithersburg, Maryland, USA. A NIST event. [Contact: Dale E. Newbury, National Institute of Standards and Technology, 100 Bureau Drive, Stop 8371, Gaithersburg, MD 20899, USA. Tel: 1 (301) 975 3921; Fax:
1 (301) 417 1321; Info: http://www.nist.gov/public_affairs/ confpage/010917.htm].

27 May-8 June 2003

High Pressure Crystallography. Erice, Italy. The 34th crystallographic course at the Ettore Majorana Centre. The course director is Prof.Andrzej Katrusiak, Adam Mickiewicz University, Department of Crystal Chemistry, ul. Grunwaldzka6, 60780 Poznan, Poland. Tel: 48 (61) 869 9181; Fax: 48 (61) 865 8008; E-mail: katran@amu.edu.pl; Info: http://www.geomin.unibo.it/orgv/erice/highpres.htm].

\section{May-6 June 2004}

Polymorphism: Solvates and Phase Relationships. Erice, Italy. The 35th crystallographic course at the Ettore Majorana Centre. The course director is Prof. Joel Bernstein of Ben Gurion University, Israel. [Contact: Prof. Lodovico Riva di Sanseverino, University of Bologna, Department of Earth and Environmental Sciences, Piazza Porta S Donato 1, 40126 Bologna, Italy. Tel: 39 (051) 243 556; Fax: 39 (051) 243 336; E-mail: riva@geomin.unibo.it; Info: http:// www.geomin.unibo.it/orgv/erice/bernstei.htm]. 